\title{
Investigation of Heavy Metals and Radionuclide's Impact on Environment Due to The Waste Products of Different Iron Processing Industries in Chittagong, Bangladesh
}

\author{
Mohammad Saifur Rahman', Bijoy Sonker Barua2, Md. Rezaul Karim1, Masud Kamal³ \\ ${ }^{1}$ Department of Chemistry, Chittagong University of Engineering and Technology, Chittagong, Bangladesh \\ ${ }^{2}$ Department of Civil Engineering, Southern University Bangladesh, Chittagong, Bangladesh \\ ${ }^{3}$ Bangladesh Atomic Energy Commission, Dhaka, Bangladesh \\ Email: saifur777@yahoo.com, bijoysonker@southern.edu.bd
}

How to cite this paper: Rahman, M.S., Barua, B.S., Karim, Md.R. and Kamal, M. (2017) Investigation of Heavy Metals and Radionuclide's Impact on Environment Due to The Waste Products of Different Iron Processing Industries in Chittagong, Bangladesh. Journal of Environmental Protection, 8, 974-989.

https://doi.org/10.4236/jep.2017.89061

Received: May 23, 2017

Accepted: August 14, 2017

Published: August 17, 2017

Copyright $\odot 2017$ by authors and Scientific Research Publishing Inc. This work is licensed under the Creative Commons Attribution International License (CC BY 4.0).

http://creativecommons.org/licenses/by/4.0/

c) (i) Open Access

\begin{abstract}
The waste products, such as induction furnace slag, ladle furnace slag, air pollution control dust, and ramming mass collected from major iron processing industries in Chittagong, Bangladesh were analyzed for heavy metals and naturally radioactive elements. The concentrations of heavy metals $\mathrm{Fe}, \mathrm{Cr}$, $\mathrm{Mn}, \mathrm{Co}, \mathrm{Cd}, \mathrm{Ni}, \mathrm{Pb}, \mathrm{Cu}$ and $\mathrm{Zn}$ were obtained from atomic absorption spectrophotometer (AAS) analysis with flame atomizer and the radioactivities due to ${ }^{226} \mathrm{Ra},{ }^{232} \mathrm{Th}$ and ${ }^{40} \mathrm{~K}$ were determined using high purity germanium (HPGe) detector of well shielded gamma-ray counting system. From the mean specific activities of the above three natural radionuclides in the investigated samples, the radium equivalent activity $\left(\mathrm{Ra}_{\mathrm{eq}}\right)$ and the external hazard index $\left(\mathrm{H}_{\mathrm{ex}}\right)$ were calculated. The study showed the prospect of contamination of environmental materials (viz., soil, water, air, plant) due to many of these investigated elements by using the collected waste products in landfill. The chemical process of ion exchange indicates that the elevated heavy metals in soil can play a role to increase the natural radioactivity of the soil. The obtained $\mathrm{Ra}_{\mathrm{eq}}$ as well as $\mathrm{H}_{\text {ex }}$ indicated the insignificant radiation hazard due to the activities of primordial radionuclides found in the investigated samples.
\end{abstract}

\section{Keywords}

Heavy Metals, Natural Radioactivity, Slag, Air Pollution Control Dust, Ramming Mass, Iron Processing Industries 


\section{Introduction}

The steel industry in Bangladesh, predominantly based in the port city of Chittagong, has appeared as a major contributor to the national economy. The rapid expansions of the shipbuilding, real estate sector as well as various infrastructure projects throughout the country are persuaded the growth of this industry. Simultaneously, huge amount of waste materials are produced. The raw materials and the process of manufacturing steel mainly induce the waste products.

In Bangladesh, the iron processing industries exploit metal scrap not iron ore. These secondary raw materials may be three categories depending on origin: i) internal scrap that falls to the floor within the plants during steel production and that is directly recovered for the production process; ii) engineering workshop scrap that arises during the working of steel in workshops, within the construction industry, on bridge building etc. and iii) scrap metal that collected from end-of-life products e.g. on demolition of structures and installations and from households. The scrap may include everything from bridge beams to household utensils. However, above $90 \%$ of these metal scrap are automobiles and ship scrap that used in these industries in Bangladesh. The secondary producers create steel by melting scrap iron. These are mostly small steel plants, and produce mild and alloy steel of given specifications in induction furnaces using scarp and sponge iron.

Along with main raw material, limestone is used as a slag former in the iron and steel making process. This is an active component in the metallurgical processes. The slag serves to bind substances which are not desired in the steel being produced. It can also provide other purposes, such as controlling the temperature of the smelting, and minimizing any re-oxidation of the finishing liquid metal product before the molten metal is removed from the furnace and used to make solid metal thereby give the steel improved properties. Slag usually contains metal oxides and silicon dioxide. Moreover, slag may comprise metal sulfides and elemental metals. Therefore, the oxides of silicon, aluminum, calcium, magnesium, iron, and smaller amounts of phosphorus, manganese, and others depending on used raw materials, are the major elements of the slags mentioned herein.

The blast furnace and the electric arc furnace generally produce basic slag. The oxygen converter and ladle furnace are the two routes of the blast and electric arc furnaces [1] respectively.

The co-products, i.e., slag of steelmaking in Bangladesh can be divided in (i) induction furnace slag and (ii) ladle furnace slag. The upper layer of first step melted iron in electric based induction furnace is removed, which is called induction furnace slag. After removing this slag, the melted iron is transferred to a ladle furnace and some chemicals $\left(\mathrm{CaO}, \mathrm{CaC}_{2}, \mathrm{CaF}_{2}, \mathrm{CaSiO}_{3} \&\right.$ Mat Cok) are added for improving the quality of iron. Finally, by electrolysis process, some unwanted materials are removed and that materials are known as ladle furnace slag. Both the induction and ladle furnace slag are basically oxide of different 
metals mentioned above and treated as waste product. Two other waste products of these iron industries in Bangladesh are (i) air pollution control dust and (ii) ramming mass. The carbon based with different fine metal particles that are released in air during the process in induction and ladle furnaces are the air pollution control dust. The composite material of boric acid $\left(\mathrm{H}_{3} \mathrm{~B}_{4} \mathrm{O}_{7}\right)$ and silica $\left(\mathrm{SiO}_{2}\right)$ is used to shield the both induction and ladle furnace from overheating and after using 20/25 heats, these are removed as waste product and appeared as super snow white crystalline quartz called ramming mass.

Out of these four wastes, the induction and ladle furnace slag are used in cement production, bricks production, as an aggregate in the base of road construction and as a land fill. The uses make them as a part of persuading the environment.

These four types of waste products contain heavy metals and many of them are toxic elements [2]. The raw materials are basically ship scraps. Ship may be used for carrying radioactive materials and seawater may be contaminated by man-made radionuclides through nuclear accident like Fukishima nuclear power plant damage or nuclear weapons tests [3]. Moreover, seawater has some natural radionuclides and these may be deposited as a crust on the outer surface of ship due to constant contact with seawater [4]. Therefore, ship scrap products may get contamination with the radionuclides and may pose radiological hazard.

Most of the heavy metals at required amount would be useful for living things. The excess amount causes to demolish it. Therefore, each of the elements has unique impact to occur the natural modification. Some metals, namely $\mathrm{Co}, \mathrm{Cu}$, $\mathrm{Fe}, \mathrm{Mn}, \mathrm{Mo}$ and $\mathrm{Zn}$, are considered to be essential for plants, $\mathrm{Cr}, \mathrm{Ni}$ and $\mathrm{Sn}$ are essential for animals, and $\mathrm{Cd}, \mathrm{Hg}$ and $\mathrm{Pb}$ have not been found to be essential for any living organism [5]. For human body the essential elements are to be considered as $\mathrm{H}, \mathrm{Na}, \mathrm{K}, \mathrm{Mg}$, Ca, Mo, Mn, Fe, Co, Cu, Zn, C, N, P, O, S, Se, Cl, I [6]. The exceeding concentrations of these elements from permissible limits will pose serious threats. According to the World Health Organization (WHO) report, the permissible limits (in $\mathrm{mg} /$ person/week) of toxic heavy metals like mercury, cadmium, lead, copper, zinc, nickel, iron, manganese are 0.35, 0.49, 1.75, 245, 490, $2.45,392$, and 68.6 respectively. While at certain times, the toxic metals may interfere with metabolic processes. The effect of toxicity on human being can decrease the energy levels and can damage the functioning of the lungs, brain, kidney, liver, blood composition and other organs.

However, the results of the concentration of heavy elements $\mathrm{Fe}, \mathrm{Cr}, \mathrm{Mn}, \mathrm{Cd}$, $\mathrm{Ni}, \mathrm{Pb}, \mathrm{Cu}, \mathrm{Zn}, \mathrm{Co}$, etc., in these waste products will be functional in environmental monitoring as well as for public awareness. Besides this elemental contamination, the present work was also undertaken to measure the level of natural radioactivity in these waste products. The radionuclides from ${ }^{238} \mathrm{U}$ and ${ }^{232} \mathrm{Th}$ decay series and ${ }^{40} \mathrm{~K}$ are mainly responsible for natural radioactivity [7] [8]. ${ }^{137} \mathrm{Cs}$ is an artificial radionuclide dispersed via radioactive fallout from nuclear weapons tests or leakage from nuclear reactor/fuel cycle plant. Therefore, the concentra- 
tion and distribution of these radionuclides in the investigated waste products are of interest.

\section{Materials and Method}

\subsection{Sample Collection}

The $90 \%$ of iron processing industries in Bangladesh are to be found at Chittagong and most of them named B Steel (B), R Steel (R), Bz Steel (Bz), and S Steel (S) were selected to collect their waste products. The extraction processes of the waste products of these industries are almost same. Induction furnace slag (IFS), ladle furnace slag (LFS), air pollution control dust (APCD), and ramming mass (RM) are concerned waste products and these were collected from the first place of wastes in the industries by taking some safeguard and then kept in a plastic bag with labeled as the type of wastes and names of the industries.

The dried bulk samples were ground by Agate Mortar to make powder. For the certain homogeneity in the sample, the investigated samples finally collected after passing through a $500 \mu \mathrm{m}$ sieve. The powdered samples collected were again oven dried at $110^{\circ} \mathrm{C}$ until constant weight was attained.

\subsection{Sample Preparation for AAS Analysis and Data Collection}

The each investigated dried and powdered sample of about $0.1 \mathrm{gm}$ was digested by aquaregia $\left(3 \mathrm{HCl}+1 \mathrm{HNO}_{3}\right)$. The chemical reagents used were of analytical grade purity: $\mathrm{HCl}-36.5 \%$, and $\mathrm{HNO}_{3}-65 \%$ (Merck, Darmstadt, Germany). The dissolved solution was filtered with mixing DI water and $1 \% \mathrm{HNO}_{3}$ and finally diluted by 12500 times. Each investigated sample had same dilution factor $(12,500$ times) and stored to analyze.

To measure the concentration of heavy metals as well as toxic elements in the investigated samples and standard samples, a Z-2000 polarized Zeeman atomic absorption spectrophotometer (AAS) was used. In this experiment, the flame method was introduced to atomize the elements contained in the samples. Each of the diluted samples was nebulized to create a fine mist of the specimen and the concentrations of heavy elements were measured by how much light is absorbed when the light flux from a light source passes through the investigated samples. The measurement mode, level and atomizer were flame $\left(\right.$ air $\left.-\mathrm{C}_{2} \mathrm{H}_{2}\right)$, ppm and standard $\left(2000^{\circ} \mathrm{C}\right)$ respectively. The oxygen pressure and measurement time were $160 \mathrm{kPa}$ and $5 \mathrm{~s} \times 3$ times respectively. The minimum detection limits of the analyzer for the investigated heavy elements in ppm are $0.002(\mathrm{Cd}), 0.02$ $(\mathrm{Cr}), 0.01(\mathrm{Cu}), 0.02(\mathrm{Fe}), 0.01(\mathrm{Mn}), 0.05(\mathrm{~Pb}), 0.005(\mathrm{Zn}), 0.03(\mathrm{Co})$ and 0.02 (Ni). The concentration of each element found from analyzer (AAS) was multiplied by 12,500 to get the actual concentration of the element in the investigated sample.

\subsection{Sample Preparation for $\gamma$-Ray Spectrometry}

For the natural radioactivity measurement, each dried sample was weighed and 
taken into individual cylindrical plastic container of $3 \mathrm{~cm}$ height and $8.3 \mathrm{~cm}$ diameter. To settle down the dry powder sample homogeneously the container was simply shaken by hand. The volume of the each sample was about $156 \mathrm{~cm}^{3}$ and kept equal to the standard gamma-ray source material. To attain the secular equilibrium between ${ }^{232} \mathrm{Th}$ and ${ }^{226} \mathrm{Ra}$ and their progeny, the investigated samples in the air tight containers were stored for four weeks before the measurement of radioactivity [9] [10].

\subsection{Radioactivity Measurements}

\subsubsection{Measurement Setup}

A coaxial high-purity germanium (HPGe) gamma-ray detector with a relative efficiency of 20\%, resolution $1.8 \mathrm{keV}$ (FWHM) at $1332 \mathrm{keV}$ of ${ }^{60} \mathrm{Co}$ was used to measure the radioactivities of the primed samples and reference samples of International Atomic Energy Agency (IAEA). A digital spectrum analyzer (DSA1000) was coupled with the used detector (GC2018, CANBERRA, USA) and the software GENIE 2000 was performed to analyze the gamma-ray spectra found from the samples. The detector was well shielded by a cylindrical $5.08 \mathrm{~cm}$ thick lead with a fix bottom and removable cover to minimize the gamma-ray background. Within this shielding arrangement, each sample was measured by placing at the surface of the detector. The counts at specific energies of the investigating samples and reference samples were taken to determine the radioactivity of the natural radioisotopes. For determining the background counts, a blank plastic container of the same geometry of the sample was used. Counting time interval was 10,000 seconds. To obtain the net peak areas, all the background counts were subtracted from original sample counts. These net peak areas, which are proportional to the radioactivity, were used to determine the concentration of radionuclides present in the investigated samples. The lower limit of detection of this HPGe gramma-ray detector for ${ }^{137} \mathrm{Cs}$ was obtained as $0.043679 \mathrm{~Bq}$.

\subsubsection{Detector Efficiency}

For bulk material, the detector efficiency is needed to determine the activity concentration of the material. The gamma-ray spectrometry method using a germanium semiconductor detector is generally used for this purpose. The gamma-ray peak efficiency versus energy curve for each objective volume sample was determined in advance of the measurements. The detection efficiency curve depends on detection system, sample shape and sample matrix. It is done by measuring the known activity of the volume samples prepared using IAEA reference samples RGU-1, RGTh-1 and RGK-1 [11].

The uranium ore and thorium ore with floated silica powder of similar grain size were used to prepare the IAEA-RGU-1 and IAEA-RGTh-1 radioactive powder reference samples respectively. These reference samples were provided by the IAEA. The reference samples namely RGU-1, RGTh-1 and RGK-1, in average $10.08 \mathrm{~g}, 10.15 \mathrm{~g}$ and $10.12 \mathrm{~g}$ respectively, were individually mixed homogeneously with $174.76 \mathrm{~g}, 174.97 \mathrm{~g}, 159.90 \mathrm{~g}$, and $159.28 \mathrm{~g}$ of investigated samples 
IFS, LFS, APCD and RM respectively to make four separate standards gammaray source materials. It was strictly followed the volume same for all the investigated and standards samples. Moreover, in the samples the radioactive equilibrium between ${ }^{226} \mathrm{Ra}$ and ${ }^{210} \mathrm{~Pb}$ were validated. The random coincidence loss made negligible by amending the distance between sample and detector and the solid angle subtended by the sample of standard radioactive sources. These four standards gamma-ray sources were used for efficiency calibration. One of the obtained efficiency curve is shown in Figure 1.

\subsubsection{Radioactivity Concentration}

A typical $\gamma$-ray spectrum of induction furnace slag (B IFS-02) is shown in Figure 2. The peaks of this spectrum were originated from the decay products of ${ }^{238} \mathrm{U}$ and ${ }^{232} \mathrm{Th}$ series and ${ }^{40} \mathrm{~K}$. The counts at peaks of energies $351.9 \mathrm{keV}$ due to the decay of ${ }^{214} \mathrm{~Pb}$ and $609.3 \mathrm{keV}$ formed in the decay of ${ }^{214} \mathrm{Bi}$ were used to measure ${ }^{226} \mathrm{Ra}$ $\left({ }^{238} \mathrm{U}\right)$ radioactivity. The ${ }^{232} \mathrm{Th}$ radioactivity was determined by $\gamma$-ray counts at peak energies $238.6 \mathrm{keV}$ and $911.2 \mathrm{keV}$ formed via the decay of the ${ }^{212} \mathrm{~Pb}$ and ${ }^{228} \mathrm{Ac}$ radionuclides respectively of thorium series. Finally, the average of the obtained values from different peak energies was taken. The radionuclide ${ }^{40} \mathrm{~K}$ was recognized by its single $\gamma$-line at energy of $1460.83 \mathrm{keV}$. It should be mentioned that the radioactivity due to ${ }^{137} \mathrm{Cs}$ in the investigated samples was found below the detection limit. The measured count rate (CPS) of gamma-ray is converted to the specific activity of the ${ }^{226} \mathrm{Ra}\left({ }^{238} \mathrm{U}\right),{ }^{232} \mathrm{Th}$ and ${ }^{40} \mathrm{~K}$ radionuclides by the following equation [12]:

$$
A=(\mathrm{CPS} \times 1000) /\left(\varepsilon_{\gamma} \times I_{\gamma} \times m\right)
$$

where, $A$ represents the specific activity $\left(\mathrm{Bq} \mathrm{kg}^{-1}\right), \varepsilon_{\gamma}$ is the efficiency of the detector for the specific photon energy, $I_{\gamma}$ is the gamma-ray intensity and $m$ (gm) is the mass of the sample. The uncertainty in the radioactivity of each sample was resolute by reflecting the uncertainties in peak area analysis (2\%), counting statistics $(1 \%-5 \%)$, detector efficiency (5\%), gamma emission probability

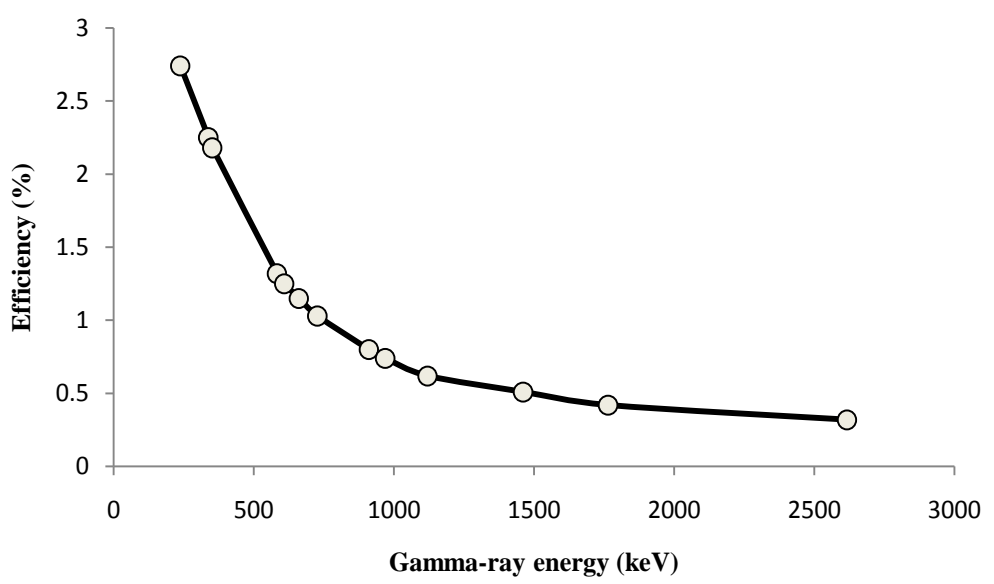

Figure 1. Efficiency of detector versus gamma-ray energy curve due to standard sample prepared for the induction furnace slag. 


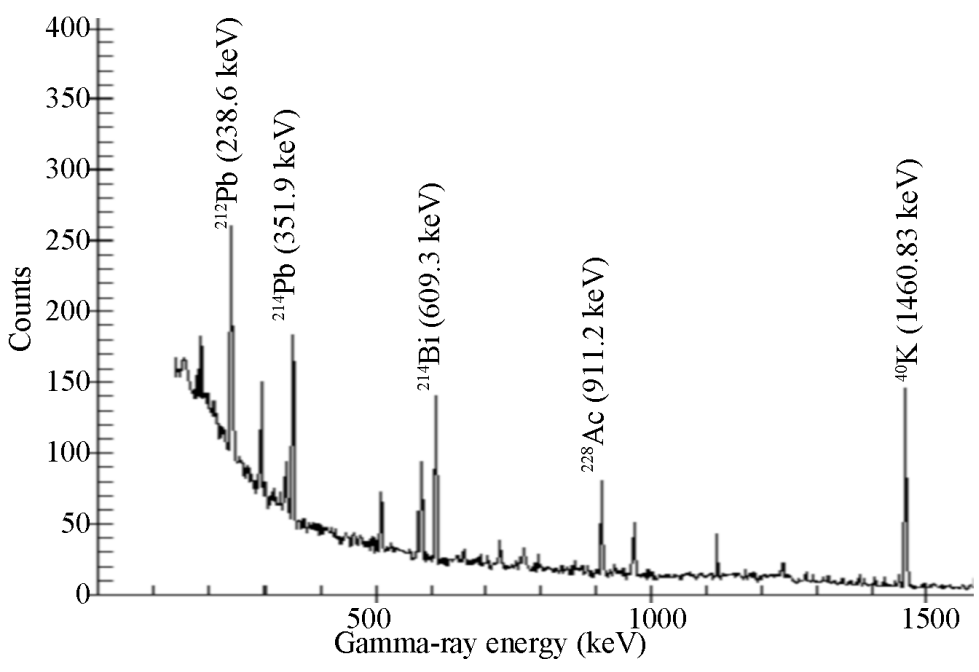

Figure 2. A typical $\gamma$-ray spectrum of induction furnace slag (B IFS-02) due to natural radionuclides.

$(<0.2 \%)$ and sample weight $(0.01 \%)$. In general the uncertainties varied from $5 \%-7 \%$. The radioactivity of each sample is being reported with the counting error of one sigma.

\subsubsection{Radiation Hazard Index Calculation}

The radium equivalent activity $\left(\mathrm{Ra}_{\mathrm{eq}}\right)$ for gamma radiation due to the major natural radionuclides had been estimated by using the following equation [12]:

$$
\mathrm{Ra}_{\mathrm{eq}}=C_{\mathrm{Ra}}+1.43 C_{\mathrm{Th}}+0.07 C_{\mathrm{K}}
$$

where $C_{\mathrm{Ra}}, C_{\mathrm{Th}}$ and $C_{\mathrm{K}}$ are the specific activities $\left(\mathrm{Bq} \mathrm{kg}{ }^{-1}\right)$ of ${ }^{226} \mathrm{Ra},{ }^{232} \mathrm{Th}$ and ${ }^{40} \mathrm{~K}$, respectively. The allowed maximum value $370 \mathrm{~Bq} \mathrm{~kg}^{-1}$ of ${ }^{226} \mathrm{Ra}$ for public dose considerations is assumed equivalent to $259 \mathrm{~Bq} \mathrm{~kg}^{-1}$ of ${ }^{232} \mathrm{Th}$ and $4810 \mathrm{~Bq} \mathrm{~kg}^{-1}$ of ${ }^{40} \mathrm{~K}$ for producing the same gamma dose rate [12].

The external hazard index $\left(H_{\mathrm{ex}}\right)$ is calculated using the Equation (3).

$$
H_{\text {ex }}=C_{\mathrm{Ra}} / 370+C_{\mathrm{Th}} / 259+C_{\mathrm{K}} / 4810
$$

The upper limit of $\mathrm{Ra}_{\mathrm{eq}}(370 \mathrm{~Bq} \mathrm{~kg}$ ) corresponds to unity is considered as a maximum value of $H_{\mathrm{ex}}$. Therefore, the value of $H_{\mathrm{ex}}$ less than unity shows the insignificant radiation hazard due to the radiation source materials [12].

\section{Results and Discussions}

\subsection{AAS Results}

\subsubsection{Reliability of Measurements}

The certified reference materials (CRM) of investigated elements ( $\mathrm{Fe}, \mathrm{Cr}, \mathrm{Mn}$, $\mathrm{Co}, \mathrm{Cd}, \mathrm{Ni}, \mathrm{Pb}, \mathrm{Cu}$ and $\mathrm{Zn}$ ) were produced and certified in accordance with ISO/IEC 17025 and ISO Guide 34. The CRM is traceable in $\mathrm{kg}$ and measured against NIST and BAM-CRM. These standard samples were found at concentration about $1000 \mathrm{ppm}$. In this work only $1 \mathrm{ml}$ of each standard sample of concentration $1000 \mathrm{ppm}$ is taken in volumetric flask and about $0.25 ; 0.50 ; 1.00 ; 1.50$ and 
$2.00 \mathrm{ppm}$ diluted solutions were prepared by adding DI water and $1 \% \mathrm{HNO}_{3}$ for each investigated element for getting the curve of each standard sample from the analyzer AAS. The curves were found linear and the correction coefficient was about 0.9998 and made our measurement reliable. Figure 3 shows one of the absorbance vs. concentration curve. Moreover, the analyzed concentration of known sample (Calculated value: $1.0939 \mathrm{ppm}$ ) by AAS was $1.0907 \mathrm{ppm}$.

\subsubsection{Metal Concentration in Investigated Samples}

The mass concentrations of elements $\mathrm{Fe}, \mathrm{Cr}, \mathrm{Mn}, \mathrm{Co}$, and $\mathrm{Zn}$ were found significantly distributed in all the four investigated samples. In induction furnace slag the concentrations of the investigated elements decreased in the order as $\mathrm{Fe}>$ $\mathrm{Mn}>\mathrm{Zn}>\mathrm{Cr}>\mathrm{Cu}>\mathrm{Co}>\mathrm{Ni}>\mathrm{Pb}$. Cadmium (Cd) was not found in this sample (Figure 4). The highest amount of $\mathrm{Fe}, \mathrm{Mn}$ and $\mathrm{Zn}$ were found in the induction furnace slag of iron processing industry $\mathrm{R}$ Steel. The elevated amount of elements $\mathrm{Ni}, \mathrm{Pb}$ and $\mathrm{Cu}$ were found in the induction furnace slag of B Steel. The highest values of $\mathrm{Cr}$ and $\mathrm{Co}$ were found in the induction furnace slag of $\mathrm{Bz}$ Steel and S Steel respectively.

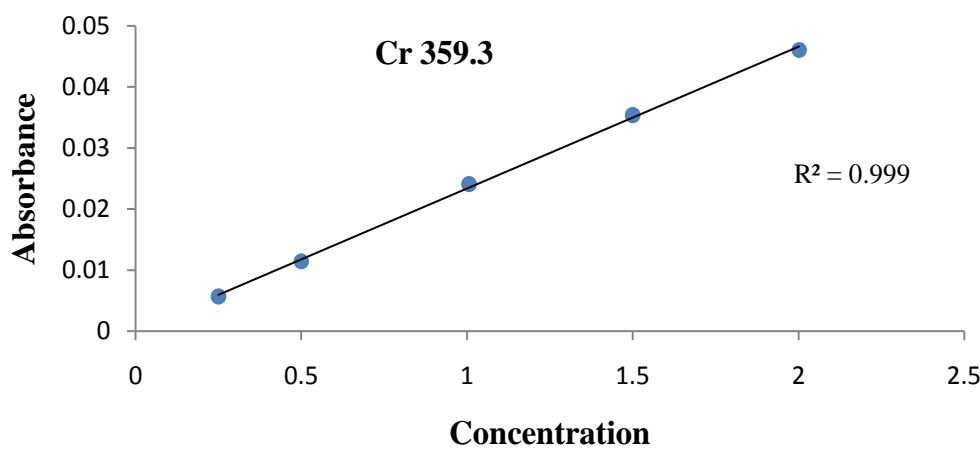

Figure 3. A typical absorbance vs. concentration curve for quantitative determination of $\mathrm{Cr}$ measurement.

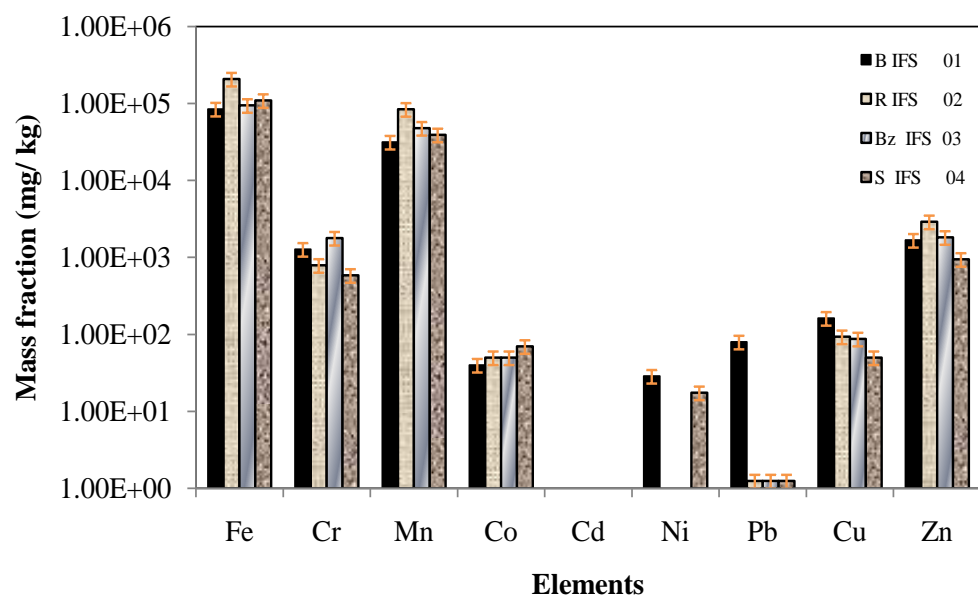

Figure 4. The average metal concentrations with standard errors (in \%) for the induction furnace slag of the four iron processing industries in Chittagong. 
The decreasing concentrations of investigated elements in the ladle furnace slag were found $\mathrm{Mn}>\mathrm{Fe}>\mathrm{Cr}>\mathrm{Zn}>\mathrm{Co}>\mathrm{Ni}$. The elements $\mathrm{Cd}, \mathrm{Pb}$ and $\mathrm{Cu}$ were not found from this sample (Figure 5). The highest amount of elements $\mathrm{Fe}$, $\mathrm{Cr}, \mathrm{Mn}$ and $\mathrm{Zn}$ were found in the ladle furnace slag of S Steel. The elevated Co element was found in the ladle furnace slag of R Steel. The element Ni was found only in the ladle furnace slag of $\mathrm{Bz}$ Steel.

All of the investigated elements were found in each air pollution control dust waste sample collected from the four iron processing industries at Chittagong (Figure 6). The concentrations of the investigated elements in this sample decreased in the order as $\mathrm{Fe}>\mathrm{Zn}>\mathrm{Pb}>\mathrm{Mn}>\mathrm{Cd}>\mathrm{Cu}>\mathrm{Cr}>\mathrm{Ni}>\mathrm{Co}$. The highest concentration of $\mathrm{Fe}, \mathrm{Cr}$ and $\mathrm{Cu}$ were found in the air pollution control dust of $\mathrm{R}$ Steel. The highest amount of $\mathrm{Mn}, \mathrm{Cd}$ and $\mathrm{Pb}$ were found in the air pollution control dust of B Steel. The elevated amount of Co was found in the same sample of S Steel. The highest value of $\mathrm{Ni}$ and $\mathrm{Zn}$ were found in the air pollution control

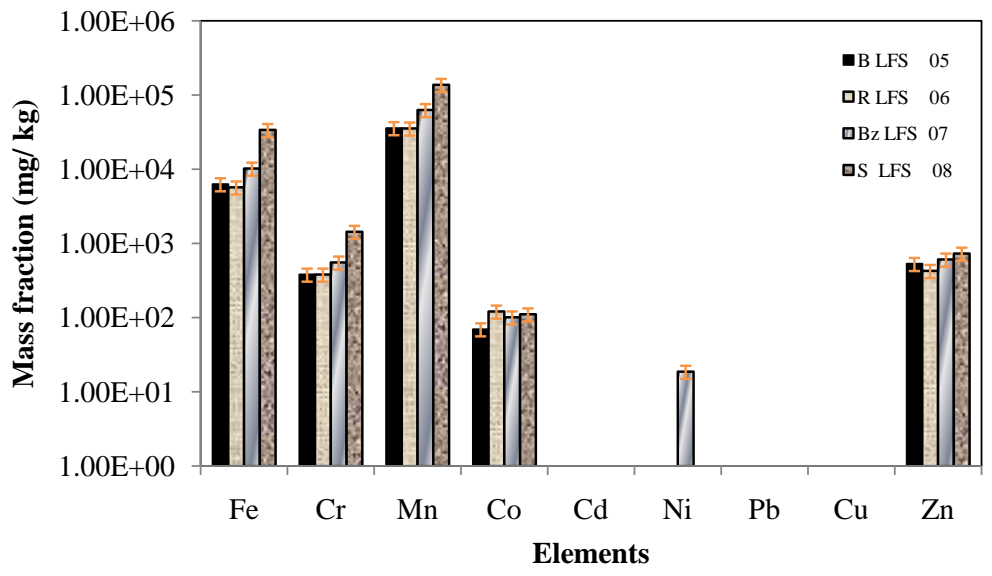

Figure 5. The average metal concentrations with standard errors (in \%) for the ladle furnace slag of the collected iron processing industries in Chittagong.

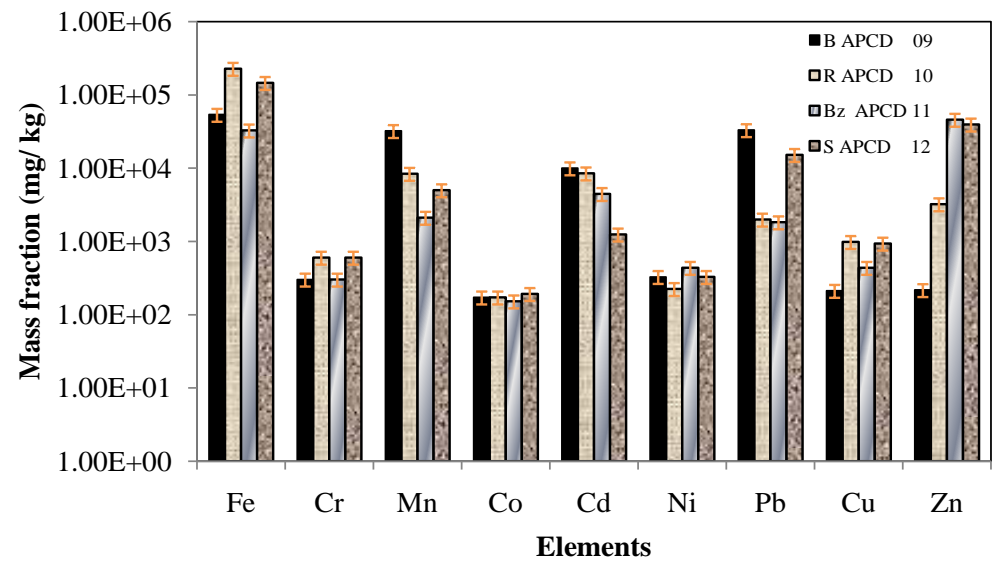

Figure 6. The average metal concentrations with standard errors (in \%) for the air pollution control dust of the investigated iron processing industries in Chittagong. 
dust of Bz Steel.

The decreased order in the concentrations of the investigated elements in the ramming mass were $\mathrm{Fe}>\mathrm{Mn}>\mathrm{Zn}>\mathrm{Cr}>\mathrm{Co}$. The elements of $\mathrm{Cd}, \mathrm{Ni}, \mathrm{Pb}$ and $\mathrm{Cu}$ were not found in this sample (Figure 7). The elevated amount of $\mathrm{Fe}$ and $\mathrm{Mn}$ were found in the ramming mass of $\mathrm{R}$ Steel. The highest concentrations of $\mathrm{Cr}$ and $\mathrm{Zn}$ were found in the same sample of $\mathrm{Bz}$ Steel and the highest value of Co was found in the ramming mass of S Steel.

Out of these four investigated waste products the induction furnace slag had the highest concentrations of Fe and Cr. Similarly, the highest value of Mn was found in ladle furnace slag. But the highest amount of all other investigated elements $\mathrm{Co}, \mathrm{Cd}, \mathrm{Ni}, \mathrm{Pb}, \mathrm{Cu}$ and $\mathrm{Zn}$ were found in air pollution control dust compare to other three investigated samples. Moreover, on the base of content of averaged concentrations of all the investigated elements the iron processing industries may be arranged in order as S Steel $>$ R Steel $>$ Bz Steel $>$ B Steel.

Table 1 shows a comparison of the present study with related literature. We

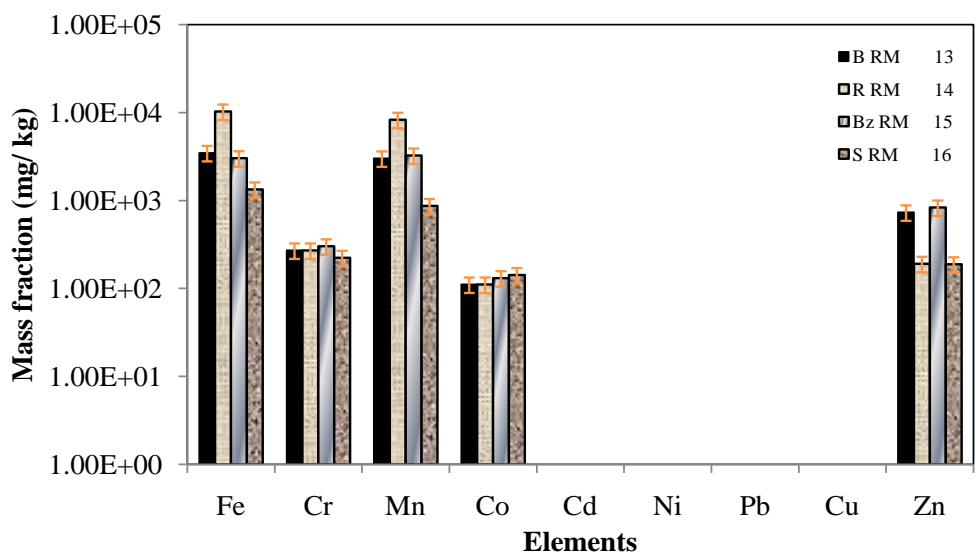

Figure 7. The average metal concentrations with standard errors (in \%) for the ramming mass of the four iron processing industries in Chittagong.

Table 1. Average metal concentrations in iron slags found in this study and in some related literature.

\begin{tabular}{|c|c|c|c|c|c|c|c|c|c|}
\hline \multicolumn{9}{|c|}{ Heavy metal concentration in iron slags (ppm) } & \multirow{2}{*}{ Reference } \\
\hline $\mathrm{Fe}$ & $C r$ & $M n$ & Co & $C d$ & $\mathrm{Ni}$ & $P b$ & $\mathrm{Cu}$ & $Z n$ & \\
\hline 430000 & 11000 & 46000 & ${ }^{*}$ nd & nd & nd & 759 & 500 & 3531 & Guinea et al. [13] \\
\hline 271100 & nd & 13800 & nd & nd & nd & $<7.50$ & nd & nd & $\begin{array}{c}\text { Alamoudi and } \\
\text { Almehmadi [14] }\end{array}$ \\
\hline 29.82 & 910 & nd & 7.86 & $<1$ & 7.44 & 6.83 & 4.21 & 9.13 & Legret et al. [15] \\
\hline 327000 & 2760 & 33300 & 50 & nd & 1000 & 2200 & 3500 & 1075000 & Rizescu et al. [16] \\
\hline 74190 & 122 & nd & nd & 13 & nd & 381 & 84 & 2528 & Zhang et al. [17] \\
\hline 16.6 & 85 & 48 & 11.1 & nd & nd & nd & 100 & 72 & Ene et al. [18] \\
\hline 124240 & 1110 & 50690 & 52.5 & ${ }^{\star}$ bd & 23.13 & 20.94 & 98.38 & 1840 & This work (IFS) \\
\hline 14029 & 689 & 67870 & 100.94 & bd & 9.38 & bd & bd & 575 & This work (LFS) \\
\hline
\end{tabular}

${ }^{\star}$ nd: not allowed to detect, ${ }^{*}$ bd: below detection. 
picked the elements from other studies that we intended in this investigation. Though, few elements were not allowed to detect in the collected studies [13]-[18]. However, the concentrations of $\mathrm{Cr}, \mathrm{Cd}$ and $\mathrm{Ni}$ found in Legret et al. [15] are mostly comparable with the ladle furnace slag of this work and the concentration of $\mathrm{Cr}$ in Legret et al. [15], Mn in Guinea et al. [13], Co in Rizescu et al. [16], and $\mathrm{Cu}$ in Zhang et al. [17] and Ene et al. [18] are found comparable with the induction furnace slag of this investigation. Further view is that the concentrations of $\mathrm{Fe}, \mathrm{Pb}$ and $\mathrm{Zn}$ found in this study are not comparable with the studies mentioned in the Table 1 . The most concern about these heavy metals is being taken these with food. The WHO's recommendation as mentioned in the introduction will be the limitations for human body.

The different concentrations of these elements found in the investigated samples as well as different iron processing industries may be consequences of extraction process and raw materials used. The waste products of slag have positive involvement in cement and brick production and in road construction but in landfill many of the toxic elements of the slags may have hazardous contribution to environment. Due to high content of lime and carbonates in slags the conductivity of leachate will be high and $\mathrm{pH}$ will be very alkaline. As an effect, land will lose its fertility. In Bangladesh these slags are often used to fill up agricultural field and coastal area. Therefore, the uptake of the toxic elements of the tree of that landfill will cause harm to human being as well as animals.

The slag is mixed with soil and sea water and enriches the elements $\mathrm{Fe}, \mathrm{Cr}$, $\mathrm{Mn}, \mathrm{Co}, \mathrm{Ni}, \mathrm{Pb}, \mathrm{Cu}$ and $\mathrm{Zn}$. Therefore, the redistribution of metal content in effected soil and sea water will play a role to change the ecosystem of the area. The excess uptake of the mentioned elements by the tree via root nutrition results to make it pollutant [19].

The range of $\mathrm{Cr}$ content in tree is $1-5 \mathrm{mg} / \mathrm{kg}$ and above the values, some metabolic alterations in plant such as decrease in chlorophyll synthesis, growth inhibition, and chlorosis can be happened [20]. The $\mathrm{Cr}$ content in slag samples found $381-1785 \mathrm{mg} / \mathrm{kg}$ in this study. The hexavalent form of $\mathrm{Cr}$ is toxic, therefore, the wide spread of $\mathrm{Cr}$ will cause a threat to environment [21].

The slag and air pollution control dust samples contained $\mathrm{Ni}$, and in this study it was found an average of $22 \mathrm{ppm}$ and $330 \mathrm{ppm}$ respectively. The high concentration of nickel creates difficulties in plant biochemistry and plant physiology [22].

The range of concentration of $\mathrm{Zn}$ found $191-46,075 \mathrm{ppm}$ in this investigation, even though most of the plants can tolerate high $\mathrm{Zn}$ levels [23].

\subsection{Results of Radioactive Concentrations}

The measured average specific activities due to terrestrial radoinuclides ${ }^{226} \mathrm{Ra}\left({ }^{238} \mathrm{U}\right),{ }^{232} \mathrm{Th}$ and ${ }^{40} \mathrm{~K}$ in induction furnace slag, ladle furnace slag, air pollution control dust and ramming mass collected from different iron processing industries at Chittagong are given in Table 2, together with the counting error of one sigma. 
Table 2. Average specific activities due to primordial radionuclides in the investigated waste products collected from different iron processing industries in Chittagong.

\begin{tabular}{|c|c|c|c|}
\hline Industry & ${ }^{226} \mathrm{Ra} \pm 1 \sigma$ & \multicolumn{2}{|c|}{${ }^{232} T h \pm 1 \sigma$} \\
\hline & \multicolumn{3}{|c|}{ Average specific radioactivity in induction furnace slag $\left(\mathrm{Bq} \mathrm{kg}^{-1}\right)$} \\
\hline B Steel & $80.37 \pm 4.80$ & $46.86 \pm 3.01$ & $132.22 \pm 7.69$ \\
\hline R Steel & $20.66 \pm 1.24$ & $22.46 \pm 1.51$ & $57.61 \pm 3.37$ \\
\hline Bz Steel & $28.60 \pm 1.85$ & $21.48 \pm 1.48$ & $167.16 \pm 9.72$ \\
\hline \multirow[t]{2}{*}{ S Steel } & $52.88 \pm 3.25$ & $54.85 \pm 3.48$ & $193.03 \pm 11.21$ \\
\hline & \multicolumn{3}{|c|}{ Average specific radioactivity in ladle furnace slag $\left(\mathrm{Bq} \mathrm{kg}^{-1}\right)$} \\
\hline B Steel & $73.35 \pm 4.36$ & $44.10 \pm 2.81$ & $70.69 \pm 4.00$ \\
\hline R Steel & $37.96 \pm 2.69$ & $38.09 \pm 2.44$ & $86.87 \pm 5.06$ \\
\hline Bz Steel & $22.31 \pm 1.45$ & $23.62 \pm 1.56$ & $122.05 \pm 7.09$ \\
\hline \multirow[t]{2}{*}{ S Steel } & $70.27 \pm 4.17$ & $56.31 \pm 3.50$ & $152.57 \pm 8.85$ \\
\hline & \multicolumn{3}{|c|}{ Average specific radioactivity in Air Pollution Control Dust $\left(\mathrm{Bq} \mathrm{kg}{ }^{-1}\right)$} \\
\hline B Steel & $21.91 \pm 1.55$ & $30.51 \pm 2.12$ & $356.81 \pm 20.73$ \\
\hline R Steel & $21.81 \pm 1.44$ & $17.36 \pm 1.18$ & $219.58 \pm 12.71$ \\
\hline Bz Steel & $11.39 \pm .79$ & $09.42 \pm 0.64$ & $105.35 \pm 6.11$ \\
\hline \multirow[t]{2}{*}{ S Steel } & $44.59 \pm 3.00$ & $28.92 \pm 2.01$ & $453.99 \pm 26.32$ \\
\hline & \multicolumn{3}{|c|}{ Average specific radioactivity in Ramming Mass $\left(\mathrm{Bq} \mathrm{kg}^{-1}\right)$} \\
\hline B Steel & $16.49 \pm 1.13$ & $19.86 \pm 1.35$ & $77.04 \pm 4.49$ \\
\hline R Steel & $5.47 \pm 0.26$ & $2.61 \pm 0.53$ & $61.87 \pm 3.61$ \\
\hline Bz Steel & $9.88 \pm 0.70$ & $16.65 \pm 1.15$ & $62.18 \pm 3.73$ \\
\hline S Steel & $26.26 \pm 1.74$ & $25.84 \pm 1.73$ & $71.81 \pm 4.19$ \\
\hline
\end{tabular}

The highest average specific activity due to ${ }^{226} \mathrm{Ra}$ and ${ }^{232} \mathrm{Th}$ were found in each sample collected from B Steel and S Steel iron processing industries. The samples collected from $\mathrm{R}$ Steel and $\mathrm{Bz}$ Steel had lowest average specific activity due to ${ }^{226} \mathrm{Ra}$ and ${ }^{232} \mathrm{Th}$. The average specific activity due to ${ }^{40} \mathrm{~K}$ all over the investigated samples varied in the range of $58-454 \mathrm{~Bq} \mathrm{~kg}^{-1}$. Moreover, in the point of concentrations of ${ }^{226} \mathrm{Ra},{ }^{232} \mathrm{Th}$ and ${ }^{40} \mathrm{~K}$, the investigated samples can be arranged as LFS $>$ IFS $>$ APCD $>$ RM for ${ }^{226} \mathrm{Ra}$, and ${ }^{232} \mathrm{Th}$, and APCD $>$ IFS $>$ LFS $>$ RM for ${ }^{40} \mathrm{~K}$.

Since the $370 \mathrm{~Bq} \mathrm{~kg}{ }^{-1}$ of ${ }^{226} \mathrm{Ra}, 259 \mathrm{~Bq} \mathrm{~kg}{ }^{-1}$ of ${ }^{232} \mathrm{Th}$ and $4810 \mathrm{~Bq} \mathrm{~kg}^{-1}$ of ${ }^{40} \mathrm{~K}$ individually produces same gamma dose rate [12], hence the average radioactivity due to ${ }^{232} \mathrm{Th}$ of the investigated samples produces higher gamma dose rate than that of ${ }^{226} \mathrm{Ra}$ and ${ }^{40} \mathrm{~K}$.

The peak due to ${ }^{137} \mathrm{Cs}$ at the energy $661 \mathrm{keV}$ was not appeared in the spectrums of investigated samples, because the radioactivity of this artificial radionuclide 
was below the detection limit.

Considering both the induction and ladle furnace slags, the average concentrations in $\mathrm{Bq} \mathrm{kg}{ }^{-1}$ were found 48,39 and 123 due to ${ }^{226} \mathrm{Ra},{ }^{232} \mathrm{Th}$ and ${ }^{40} \mathrm{~K}$ respectively in this study. The activities for the two series of ${ }^{232} \mathrm{Th}$ and ${ }^{238} \mathrm{U}$ in the alike samples were found $150 \mathrm{~Bq} \mathrm{~kg}^{-1}$, [24] that are greater than the results determined in this investigation for ${ }^{226} \mathrm{Ra}$, and ${ }^{232} \mathrm{Th}$. The reported values $110.65,102.4$ and $10.58 \mathrm{~Bq} \mathrm{~kg}{ }^{-1}$ due to ${ }^{226} \mathrm{Ra},{ }^{232} \mathrm{Th}$ and ${ }^{40} \mathrm{~K}$ respectively in iron slag [14] are not comparable with this experiment. However, the reported values 53.4, 28.8 and $97.4 \mathrm{~Bq} \mathrm{~kg}^{-1}$ for ${ }^{238} \mathrm{U},{ }^{232} \mathrm{Th}$ and ${ }^{40} \mathrm{~K}$ respectively, for iron slag samples produced in Egypt [25] are consistent to our analyzed values.

In the coastal area as well as in the marine environment, the geographical composition of the soil/sediment makes some variation in the concentrations of ${ }^{238} \mathrm{U}$, ${ }^{232} \mathrm{Th}$ and ${ }^{40} \mathrm{~K}[26]$.

One of the important process of ion exchange from $\mathrm{Fe}(\mathrm{OH})_{3}$, where Fe (III) enhances the accumulation of uranium and thorium in soils/sediments from seawater or other sources [27].

Slag or other waste products of iron processing industries used in landfill in the coastal area content higher amount of $\mathrm{Fe}, \mathrm{Cr}, \mathrm{Mn}, \mathrm{Ni}, \mathrm{Pb}, \mathrm{Cu}$, etc. and these elements can play an important role to remove uranium and thorium from the seawater in soils/sediments. Therefore, the land filled with these waste products may affect the geological properties of the soil [27] [28] [29] and the elemental contamination elevates the natural radioactivity of the soil.

\section{Hazard Index}

The measured activities of ${ }^{226} \mathrm{Ra},{ }^{232} \mathrm{Th}$ and ${ }^{40} \mathrm{~K}$ were used to calculate the radium equivalent activity and external hazard index and the results are given in Table 3. The obtained variations in different investigated samples are eventually followed by the specific activity of the respective samples. The radium equivalent activities of all investigated samples varied from 9.75 to $171.4 \mathrm{~Bq} \mathrm{~kg}^{-1}$, were found lesser than the maximum value of public dose consideration $\left(370 \mathrm{~Bq} \mathrm{~kg}{ }^{-1}\right.$ ) and hence acceptable of safe use [30]. The corresponding results of external hazard index in this study $(0.03$ - 0.47$)$ were obtained lower than unity, therefore, the radiation hazard found low due to the studied samples.

Table 3. Hazard indices calculated from the measured specific radioactivities in the waste products of B Steel, R Steel, Bz Steel and S Steel iron processing industries in Chittagong.

\begin{tabular}{ccc}
\hline \multirow{2}{*}{ Sample Name } & Radium equivalent activity $(B q / \mathrm{kg})$ & External hazard index \\
\cline { 2 - 3 } & Range & Range \\
\hline Induction furnace slag & $56.55-162.90$ & $0.15-0.44$ \\
Ladle furnace slag & $53.43-171.40$ & $0.15-0.47$ \\
Air pollution control dust & $15.25-131.30$ & $0.04-0.36$ \\
Ramming mass & $9.75-70.57$ & $0.03-0.19$ \\
\hline
\end{tabular}




\section{Conclusion}

The waste products collected from major iron processing industries in Chittagong were carefully analyzed to determine heavy metal by AAS and natural radioactivity by HPGe gamma-ray spectrometry. Regarding all the investigated samples the average concentrations of the investigated elements decreased in order as $\mathrm{Fe}>\mathrm{Mn}>\mathrm{Pb}>\mathrm{Zn}>\mathrm{Cd}>\mathrm{Cr}>\mathrm{Cu}>\mathrm{Ni}>\mathrm{Co}$. Out of the four types of investigated samples, air pollution control dust contained all the investigated elements and the ramming mass contained less number of elements. Many of these elements are toxic and quantitatively high in the waste products and therefore soil, water, and air may be contaminated by mixing with these waste samples and cause some harmful impact in the environment. The higher amount of $\mathrm{Fe}, \mathrm{Cr}, \mathrm{Mn}, \mathrm{Ni}, \mathrm{Pb}, \mathrm{Cu}$, etc. in slag used in land fill may play a role in removal of natural radionuclides from sea water and deposition in the soil. In $\gamma$-ray spectrums of the investigated samples no peak at $661 \mathrm{keV}$ from the decay of ${ }^{137} \mathrm{Cs}$ activity was found. Moreover, in radioactive concern the results reflect that the investigated waste products of iron processing industries in Chittagong seem radiologically safe for human beings. The results obtained by this study would be functional to prohibit the use of these waste products.

\section{Acknowledgements}

The authors thank to the authority of Chittagong University of Engineering and Technology, Chittagong, Bangladesh and Atomic Energy Centre, Bangladesh Atomic Energy Commission, Chittagong, Bangladesh for providing all sorts of experimental opportunity and fund. The authors would like to acknowledge the help of the authority of investigated iron processing industries at Chittagong for providing samples and information.

\section{References}

[1] Fruehan, R. (1998) The Making, Shaping, and Treating of Steel, Steelmaking and Refining Volume. The AISE Steel Foundation, Pittsburgh.

[2] Katz, S. (2004) "Slags" Effects on Cast Iron Production. AFS Transactions American Foundry Society, Des Plaines and Katz Associates, West Bloomfield, 04-132(05), 1-13.

[3] Barua, B.S., Uddin, M., Shariff, M., Bhuian, A.S., Kamal, M. and Rashid, M.A. (2013) Study on Radiological Contamination of Ship Scraps and Environmental Materials in Ship Breaking Area of Chittagong, Bangladesh. Radiation Protection and Environment, 36, 52-56. https://doi.org/10.4103/0972-0464.128867

[4] Uddin, M.S., Barua, B.S., Shariff, M.A., Hasan, M.M., Rashid, M.A. and Kamal, M. (2014) Investigation of Elemental and Radiological Contamination of Soils in Two Shipyards in Chittagong, Bangladesh. Radiochimica Acta, 102, 741-749. https://doi.org/10.1515/ract-2013-2197

[5] Misra, S.G. and Mani, D. (1991) Heavy Metals Pollutant in: Soil Pollution. Ashish Publishing House, New Delhi, 60.

[6] UCDAVIS, University of California (2017). 
https://chem.libretexts.org/Textbook_Maps/General_Chemistry_Textbook_Maps/ Map\%3A_Chemistry_(Averill_and_Eldredge)/01\%3A_Introduction_to_Chemistry/ 1.8_Essential_Elements_for_Life

[7] Kessaratikoon, P. and Awaekechi, S. (2008) Natural Radioactivity Measurement in Soil Samples Collected from Municipal Area of Hat Yai District in Songkhla Province, Thailand. KMITL Science and Technology Journal, 8, 52-58.

[8] Shabana, E.I., Abulfaraj, W.H., Kinsara, A.A. and Rizaiza, O.S.A. (2013) Natural Radioactivity in the Groundwater of Wadi Nu'man, Mecca Province, Saudi Arabia. Radiochimica Acta, 101, 461-470. https://doi.org/10.1524/ract.2013.2043

[9] Debertin, K. and Helmer, R.G. (1980) Gamma and X-Ray Spectrometry with Semiconductor Detectors. Elsevier, Amsterdam.

[10] Schőtzig, U. and Debertin, K. (1983) Photon Emission Probabilities per Decay of ${ }^{226} \mathrm{Ra}$ and ${ }^{232} \mathrm{Th}$ in Equilibrium with Their Daughter Products. Applied Radiation and Isotopes, 34, 533-538.

[11] International Atomic Energy Agency (IAEA) (1987) Radiometric Reference Materials; RGU-1, RGTh-1 and RGK-1. IAEA Report No. RL/148, Vienna.

[12] Beretka, J. and Mathew, P.J. (1985) Natural Radioactivity of Australian Building Materials, Industrial Wastes and By-Products. Health Physics, 48, 87-95. https://doi.org/10.1097/00004032-198501000-00007

[13] Guinea, J.G., Correcher, V., Vazquez, C., Feo, L.R.E., Martin, R.G. and Tormo, L. (2010) Influence of Accumulation of Heaps of Steel Slag on the Environment: Determination of Heavy Metals Content in the Soils. The Anais da Academia Brasileira de Ciências, 82, 137-147.

[14] Alamoudi, Z.M. and Almehmadi, F.G. (2013) Concentrations of the Naturally Occurring Radioactive Materials in Waste Samples from Iron Production, the Carbon Filters Used in Saudi Arabia. Life Science Journal, 10, 641-647.

[15] Legret, M.A., Chaurand, P.B., Bénard, A.C., Capowiez, Y.D., Deneele, D.A., Reynard, J.E., Lassabatere, L.A., Yilmaz, D.A., Rose, J.B., Domas, J.E., Béchet, B.A., Richard, D.F. and Bottero, J.Y.B. (2009) Environmental Assessment of a BOF Steel Slag Used in Road Construction: The ECLAIR Research Program. Publication Scientifiques en acceslibre de P INERIS, Wascon 2009, Jun 2009, 6 p.

[16] Rizescu, C.Z., Stoian, E.V., Ittu, C., Ungureanu, D.N. and Bacinschi, Z. (2011) Heavy Metals Dust from Electric Arc Furnace. In: International Conference on Biomedical Engineering and Technology, Vol. 11, IACSIT Press, Singapore.

[17] Zhang, C.Q., Piper, J.D. and Huang, B. (2011) Assessment of Heavy Metal Pollution from a Fe-Smelting Plant in Urban River Sediments Using Environmental Magnetic and Geochemical Methods. Environmental Pollution, 159, 3057-3070.

[18] Ene, A. and Pantelică, A. (2011) Characterization of Metallurgical Slags Using LowLevel Gamma-Ray Spectrometry and Neutron Activation Analysis. Roman Journal of Physics, 56, 1011-1018.

[19] Berlizov, A.N., Blum, O.B., Filby, R.H., Malyuk, I.A. and Tryshyn, V.V. (2007) Testing Applicability of Black Poplar (Populus nigra L) Bark to Heavy Metal Air Pollution Monitoring in Urban and Industrial Regions. Science of the Total Environment, 372, 693.

[20] Dube, B.K., Tewari, K., Chatterjee, J. and Chatterjee, C. (2003) Excess Chromium Alters Uptake and Translocation of Certain Nutrient in Citrullus. Chemosphere, 53, 1147.

[21] Palit, S., Sharma, A. and Talukder, G. (1994) Effect of Cobalt on Plants. The Botanical Review, 60, 149. https://doi.org/10.1007/BF02856575 
[22] Severne, B.C. and Brooks, R.R. (1972) A Nickel Accumulating Plant in Western Australia. Planta, 103, 91-94. https://doi.org/10.1007/BF00394610

[23] Pundyte, N., Baltrenaite, E., Pereira, P. and Paliulis, D. (2011) Anthropogenic Effects on Heavy Metals and Macronutrients Accumulation in Soil and Wood of Pinus sylvestris L. Journal of Environmental Engineering and Lands Management, 19, 34. https://doi.org/10.3846/16486897.2011.557473

[24] UNSCEAR United Nations Scientific Committee on the Effects of Atomic Radiation (2000) Report of UNSCEAR to the General Assembly. Vol. 1, Sources and Effects of Ionizing Radiation. United Nations, New York, 91-125.

[25] Ibrahiem, N.A., Nada, M., Abd Elmaksoud, T.M., El-Ezaby, B. and Abd El Azeem, S.A. (2000) Concentrations in Coal and Its End Product in Steel Production. Paper Presented at the 10th International Radiation Protection Association, IRPA, P-1a-31, Hiroshima.

[26] Stricht, E.V.D. and Kirchmann, R. (2001) Radioecology, Radioactivity and Ecosystems. Fortemps, Liege, 219-303.

[27] Rachkova, N.G., Shuktomova, I.I. and Taskaev, A.I. (2010) The State of Natural Radionuclides of Uranium, Radium and Thorium in Soils. Eurasian Soil Science, 43, 651-658. https://doi.org/10.1134/S1064229310060050

[28] Legin, E.K., Trifonov, Y.I., Khokhlov, M.L., Suglobov, D.N. and Legina, E.E. (2003) Effect of Bioreduction of Iron in Soils on Migration Behavior of Radionuclides and Heavy Metals. In: Proceeding of the Khlopin Radium Institute, V. G. Khlopin Radium Institute, Ploschud Muzhestva, 148.

[29] Štrok, M., Smodiš, B. and Petrinec, B. (2010) Natural Radionuclides in Sediments and Rocks from Adriatic Sea. Journal of Radioanalytical and Nuclear Chemistry, 286, 303-308. https://doi.org/10.1007/s10967-010-0705-3

[30] OECD Organization for Economic Cooperation and Development (1979) Report by a Group of Experts of the OECD Nuclear Energy Agency. Rue Andre-Pascal, Paris.

Submit or recommend next manuscript to SCIRP and we will provide best service for you:

Accepting pre-submission inquiries through Email, Facebook, LinkedIn, Twitter, etc. A wide selection of journals (inclusive of 9 subjects, more than 200 journals)

Providing 24-hour high-quality service

User-friendly online submission system

Fair and swift peer-review system

Efficient typesetting and proofreading procedure

Display of the result of downloads and visits, as well as the number of cited articles

Maximum dissemination of your research work

Submit your manuscript at: http://papersubmission.scirp.org/

Or contact jep@scirp.org 